\title{
Physiological stress and higher reproductive success in bumblebees are both associated with intensive agriculture
}

Tatjana Krama ${ }^{1}$, Ronalds Krams ${ }^{2}$, Maris Munkevics ${ }^{3}$, Jonathan Willow ${ }^{2}$, Sergejs Popovs ${ }^{1}$, Didzis Elferts ${ }^{3}$, Linda Dobkevica $^{3}$, Patricija Raibarte ${ }^{3}$, Markus J. Rantala ${ }^{4}$, Jorge Contreras Garduño ${ }^{5}$, Indrikis A Krams ${ }^{\text {Corresp. } 6}$

1 Daugavpils University, Daugavpils, Latvia

2 Estonian University of Life Sciences, Tartu, Estonia

3 University of Latvia, Riga, Latvia

4 University of Turku, Turku, Finland

5 Universidad Nacional Autónoma de México, Morelia, Mexico

6 University of Tartu, Tartu, Estonia

Corresponding Author: Indrikis A Krams

Email address: indrikis.krams@ut.ee

Free-living organisms face multiple stressors in their habitats, and habitat quality often affects development and life history traits. Increasing pressures of agricultural intensification have been shown to influence diversity and abundance of insect pollinators, and it may affect their elemental composition as well. We compared reproductive success, body concentration of carbon $(\mathrm{C})$ and nitrogen $(\mathrm{N})$, and $\mathrm{C} / \mathrm{N}$ ratio, each considered as indicators of stress, in the buff-tailed bumblebee (Bombus terrestris). Bumblebee hives were placed in oilseed rape fields and semi-natural old apple orchards. Flowering season in oilseed rape fields was longer than that in apple orchards. Reproductive output was significantly higher in oilseed rape fields than in apple orchards, while the $\mathrm{C} / \mathrm{N}$ ratio of queens and workers, an indicator of physiological stress, was lower in apple orchards, where bumblebees had significantly higher body N concentration. We concluded that a more productive habitat, oilseed rape fields, offers bumblebees more opportunities to increase their fitness than a more natural habitat, old apple orchards, which was achieved at the expense of physiological stress, evidenced as a significantly higher $\mathrm{C} / \mathrm{N}$ ratio observed in bumblebees inhabiting oilseed rape fields. 


\section{Physiological stress and higher reproductive success in bumblebees}

\section{3 are both associated with intensive agriculture}

5 Tatjana Krama ${ }^{1,2}$, Ronalds Krams ${ }^{1,2}$, Māris Munkevics ${ }^{2,3}$, Jonathan Willow ${ }^{1}$, Sergejs Popovs ${ }^{2}$,

6 Didzis Elferts ${ }^{4}$, Linda Dobkeviča ${ }^{5}$, Patrīcija Raibarte ${ }^{3}$, Markus J. Rantala ${ }^{6}$, Jorge Contreras

7 Garduño ${ }^{7}$, Indrikis A. Krams ${ }^{2,3,8}$

$9{ }^{1}$ Chair of Plant Health, Estonian University of Life Sciences, Tartu 51006, Estonia

$10 \quad{ }^{2}$ Department of Biotechnology, Daugavpils University, Daugavpils 5401, Latvia

$11{ }^{3}$ Department of Zoology and Animal Ecology, Faculty of Biology, University of Latvia, Rīga

12 1004, Latvia

$13{ }^{4}$ Department of Botany and Ecology, Faculty of Biology, University of Latvia, Rīga 1004,

14 Latvia

$15{ }^{5}$ Department of Environmental Science, Faculty of Geography and Earth Sciences, University of 16 Latvia, Rīga 1004, Latvia

$17{ }^{6}$ Department of Biology, Section of Ecology, University of Turku, Turku 20014, Finland

$18{ }^{7}$ Escuela Nacional de Estudios Superiores Unidad Morelia, Universidad Nacional Autónoma de

19 México, Morelia 58190, Mexico

$20{ }^{8}$ Institute of Ecology and Earth Sciences, University of Tartu, Tartu 51010, Estonia

22 Correspondence: Indrikis A. Krams; indrikis.krams@ut.ee 


\section{Abstract}

25

26 Free-living organisms face multiple stressors in their habitats, and habitat quality often affects

27 development and life history traits. Increasing pressures of agricultural intensification have been

28 shown to influence diversity and abundance of insect pollinators, and it may affect their

29 elemental composition as well. We compared reproductive success, body concentration of

30 carbon $(\mathrm{C})$ and nitrogen $(\mathrm{N})$, and $\mathrm{C} / \mathrm{N}$ ratio, each considered as indicators of stress, in the buff-

31 tailed bumblebee (Bombus terrestris). Bumblebee hives were placed in oilseed rape fields and

32 semi-natural old apple orchards. Flowering season in oilseed rape fields was longer than that in

33 apple orchards. Reproductive output was significantly higher in oilseed rape fields than in apple

34 orchards, while the $\mathrm{C} / \mathrm{N}$ ratio of queens and workers, an indicator of physiological stress, was

35 lower in apple orchards, where bumblebees had significantly higher body $\mathrm{N}$ concentration. We

36 concluded that a more productive habitat, oilseed rape fields, offers bumblebees more

37 opportunities to increase their fitness than a more natural habitat, old apple orchards, which was

38 achieved at the expense of physiological stress, evidenced as a significantly higher $\mathrm{C} / \mathrm{N}$ ratio

39 observed in bumblebees inhabiting oilseed rape fields.

41 Keywords: agricultural landscape, bumblebees, the carbon-to-nitrogen ratio, ecological

42 stoichiometry, pollinators, reproductive stress 


\section{Introduction}

While pollination is one of the most important ecosystem services for ensuring crop productivity, both agricultural intensification and agricultural land expansion have negatively affected pollinator species and community diversity (Kremen, Williams \& Thorp, 2002; Garibaldi et al., 2013; Lever et al., 2014). This is an important economic argument for conservation of local pollinators and their habitats (Goulson, 2012). However, despite the numerous conservation measures in place, insect pollinators remain under constant stress, especially in areas of highintensity agriculture, as a result of continuous changes in the landscape and microclimate, invasive pests and diseases, decreases in the amount of floral resources, and the detrimental effects of pesticides (Goulson et al., 2015; Crall et al., 2018). Moreover, recent studies have demonstrated that minor variations in vegetation traits significantly affect habitat quality, pollinator immunity, stress resistance and abundance (Riddell \& Mallon, 2006; Bartual et al.,

61 2019; Jachuła, Denisow \& Wrzesień, 2021).

62

63 It is known that body elemental composition responds to environmental stress (Sterner \& Elser, 64 2002; Hawlena \& Schmitz, 2010a; Huang, Wang \& Ren, 2019). Body carbon (C) and body 65 nitrogen $(\mathrm{N})$ concentrations follow to changes in environmental quality (De Senerpont Domis et 66 al., 2014; Janssens, Op de Beeck \& Stoks, 2017), environmental stability (Janssens, Van Dievel 67 \& Stoks, 2015a; Schmitz, Rosenblatt \& Smylie, 2016; Zhang et al., 2016), individual development-associated stress (Trakimas et al., 2019; Krams et al., 2020), and the risk of predation (Janssens, Van Dievel \& Stoks, 2015b; Van Dievel, Janssens \& Stoks, 2016; Krams et 
70 al., 2016; Zhang et al., 2016; Krams et al., 2021a). Stress is supposed to increase

71 glucocorticosteroid release, which heightens the intensity of metabolism (Slos \& Stoks, 2008;

72 Hawlena \& Schmitz, 2010a,b; Krams et al., 2013b,a). This typically leads to higher consumption

73 of carbohydrates (Hawlena \& Schmitz, 2010a; Rinehart \& Hawlena, 2020), the increased

74 concentration of body $\mathrm{C}$, reduced concentration of body N, and a higher $\mathrm{C} / \mathrm{N}$ ratio (Sterner \&

75 Elser, 2002; Hawlena \& Schmitz, 2010a,b; Trakimas et al., 2019; Van Dievel, Janssens \& Stoks, 76 2020).

77

78 In pollinator research, ecological stoichiometry has been used to study relationships between the chemical content and quality of bee food, and the consequences these may cause on the individual development of bees and the diversity of local pollinator communities (Filipiak \&

81 Weiner, 2017; Filipiak et al., 2017). The maintenance of stoichiometric balance is important

82 because inconsistency between the chemical composition of an organism's tissues and that of its

83 food sources strongly affects the organism's life history traits, including fitness (Filipiak, 2018;

84 Filipiak, Woyciechowski \& Czarnoleski, 2021). This suggests that the availability of suitable

85 food and its elemental composition may influence the stoichiometric balance of individual 86 pollinators (Simanonok \& Burkle, 2020). The stoichiometric phenotype of pollinators has been

87 shown to affect plant-herbivore interactions, the diversity of local communities, and the quality 88 of pollination services performed (Filipiak \& Weiner, 2017; Kämper et al., 2017).

90 The concentration of body $\mathrm{C}$ and $\mathrm{N}$ in bumblebees has been studied to understand the variation 91 of $\mathrm{C}$ and $\mathrm{N}$ among social castes and sexes of the buff-tailed bumblebee (Bombus terrestris) in an 92 agricultural landscape (Krams et al., 2021b). To understand the suitability of ecological 
93 stoichiometry based on variations of body $\mathrm{C}$ and $\mathrm{N}$ and the $\mathrm{C} / \mathrm{N}$ ratio as indicators of bumblebee

94 stress, comparative research should be done to compare the body $\mathrm{C}$ and $\mathrm{N}$ of bumblebees in

95 habitats resembling natural ones and areas of high-intensity agriculture. A recent study shows

96 that close proximity to forests favors bumblebee abundance and diversity because forests support

97 wild pollinators also in nearby agricultural landscapes (Sõber et al., 2020). Due to the presence

98 of several layers of vegetation in apple orchards, we considered this to be a more natural habitat

99 than oilseed rape fields.

101 In this study, we investigated whether habitat affects ecological stoichiometry in the bodies of $B$.

102 terrestris adults. We predicted that $B$. terrestris individuals living in more natural habitats such

103 as old apple orchards grown with no pesticides used should have higher body $\mathrm{N}$ concentrations,

104 lower body $\mathrm{C}$ concentrations, and lower $\mathrm{C} / \mathrm{N}$ ratios than $B$. terrestris individuals inhabiting

105 intensive agricultural landscapes such as oilseed rape fields. Apple orchards consist of trees, and

106 habitats containing more trees can be considered as habitats supporting higher biodiversity and

107 abundance of wild bumblebees (Martínez-Sastre, Miñarro \& García, 2020; Sõber et al., 2020). A

108 previous study (Krams et al., 2021b) showed that body $\mathrm{N}$ concentration and body $\mathrm{C} / \mathrm{N}$ ratio

109 depend on $B$. terrestris caste, sex and queen age, while body $\mathrm{C}$ concentration does not

110 significantly differ between bumblebee types (castes, ages and between young and ovipositing

111 queens). Based on these results (Krams et al., 2021b), we predicted that workers and young

112 queens might have higher $\mathrm{N}$ concentrations and lower $\mathrm{C} / \mathrm{N}$ ratios than ovipositing queens and

113 males. However, the flowering period of oilseed rape is estimated to reach one month

114 (d'Andrimont et al., 2020) or longer in northern conditions as are present in Latvia, whereas 
115 apple trees bloom for only up to 10 days (Tromp, 1976). This suggests that bumblebee colonies

116 can have access to larger amounts of food resources in oilseed rape fields than in apple orchards.

118

119 Materials \& Methods

120

121 Study sites and insects

122

123 The study was carried out using commercially grown B. terrestris (Biobest Group NV, Westerlo,

124 Belgium). At the beginning of May 2020, we placed B. terrestris hives in two contrasting

125 habitats in southeast Latvia near Krāslava: oilseed rape fields and apple orchards. We had a total

126 of 50 hives across 28 oilseed rape fields and 22 hives across 11 apple orchards. At each study

127 site, we placed one to three colonies, each protected against ant and rodent attacks by attaching

128 sticky tape around the lower parts of each hive. We weighed each hive and removed the plastic

129 container with a feeding solution attached to each hive by the producer. We regularly observed

130 each colony to make sure the colonies were in good condition.

131

132 The apple orchards were located on private properties, and their size ranged from $2-4$ ha. The

133 orchards were partially surrounded by semi-natural forest vegetation in the form of mixed-

134 species unmanaged patches of alders, oaks, pines, spruces, and hedgerows. The apple orchards

135 represented old, semi-natural ecosystems with low commercial value. The average age of apple

136 trees was $44.24 \pm 6.12$ years. The ground level was covered by blackcurrant (Ribes nigrum), 
137 redcurrant (Ribes rubrum) and gooseberry (Ribes divaricatum) bushes and grasses typical for

138 local meadows, and cut for hay twice during spring-summer.

139

140 The nearest oilseed rape fields were located 3-6 km away from the apple orchards. The fields

141 were c. 20-50 ha in size and were located in a mosaic of landscape as described earlier (Krams et

142 al., 2021b). We chose our study sites so that bumblebee hives were located between fields of

143 spring- and winter oilseed rape.

144

145 We collected hives for their content analyses at the beginning of July just as they reached

146 generative offspring production phase. The collection was done similarly as described in our

147 earlier work (Krams et al., 2021b). Prior to collection we closed exit holes of the hive for 7-9

148 hours and hives were stored in a freezer at $-84{ }^{\circ} \mathrm{C}$ (Angelantoni Lifescience, Italy).

150 Nest variables

151

152 For each nest, we checked for the presence of ovipositing queens, and recorded the total number

153 of hatched and unhatched cells. Since all hives contained males and young queens, all pupae

154 were assumed to be next-generation offspring, and were thus included as a measure of

155 reproductive success. The number of worker- and queen cells reflect reproductive effort, and

156 since reproduction is costly, these numbers can be used to estimate the levels of reproduction-

157 associated stress.

158

159 Bumblebee body mass, body $\mathbf{C}$ and $\mathbf{N}$ concentration 
161 We dried the bumblebees at $65^{\circ} \mathrm{C}$ for $72 \mathrm{~h}$, and weighed individual insects using a Precisa semi-

162 micro balance (ES 225SM-DR; Precisa Gravimetrics AG, Dietikon, Switzerland) to obtain their

163 dry mass. Pollen was removed from the body or workers before we dried and weighed

164 bumblebees. Individual bumblebees were homogenized and we obtained their whole body $\mathrm{C}$ and

$165 \mathrm{~N}$ mass percentage using the element analyzer EuroVector EA3000 (Eurovector Srl, Pavia, Italy)

166 (Krams et al., 2020, 2021a). Samples of C and N concentrations were measured for each

167 bumblebee. We had 50 ovipositing queen samples (22 collected from apple orchards, 28 from

168 oilseed rape fields), 52 young queen samples (27 from apple orchards, 25 from oilseed rape

169 fields), 63 worker samples (28 from apple orchards, 35 from oilseed rape fields), and 55 male

170 samples (29 from apple orchards, 26 from oilseed rape fields).

171

172 Statistics

173

174 We used the Gamma (with log link) generalized linear mixed-effects models (GLMMs) using

175 habitat, bumblebee sex and interaction between habitat and sex as independent variables, and

176 body mass, body $\mathrm{C}$, and $\mathrm{C} / \mathrm{N}$ ratio as dependent variables as those variables showed problems

177 with heterogeneity. Linear mixed-effects models (LMEs) with the same independent variables

178 were used for body N concentration. In all four models, Site identity (ID) and Hive ID were used

179 as nested random factors.

180

181 A Poisson (with log link) GLMM was used to assess the effect of habitat (independent variable)

182 on the number of intact worker cocoons, eclosed worker cocoons, total number of worker 
183 cocoons, intact queen cocoons, eclosed queen cocoons, total number of queen cocoons, number

184 of pollen cells and number of wax cells (dependent variables). As the models showed

185 overdispersion, Hive ID was added as the observation-level random effects, in addition to Site ID

186 that was also set as a random factor in all eight Poisson GLMMs. We performed post-hoc

187 comparison between bumblebee types (workers, young queens, ovipositing queens, males) using

188 pairwise Tukey-adjusted comparison of estimated marginal means from the model. Overall

189 significance of each factor and their interaction was expressed as analysis of deviance tables

190 (Type II Wald chi-square tests) for Gamma and Poisson GLMM, and analysis of variance table

191 with Satterthwaite's method for LME. For the Gamma and Poisson GLMM, post-hoc test

192 comparisons were evaluated using z-value, but t-value for LME. All analyses were performed in

193 R v4.0.4 (R Core Team, 2021) libraries lme4 (Bates et al., 2015) for GLMM and LME models,

194 lmerTest (Kuznetsova, Brockhoff \& Christensen, 2017) for obtaining $p$-values of models, and

195 emmeans (Lenth, Buerkner \& Herve, 2021) for post-hoc tests. The significance threshold for all

196 tests was set at $p=0.05$.

197

198

199 Results

200

201 Body mass

202

203 The body mass was significantly affected by bumblebee types $\left(\chi_{(3)}^{2}=693.27, p<0.0001\right.$; Fig.

204 1). However, body mass was not affected by habitat $\left(\chi_{(1)}^{2}=1.42, p=0.23\right)$ nor

205 habitat-bumblebee type interaction $\left(\chi_{(3)}^{2}=4.35, p=0.23\right)$. 
207 Regarding specimens collected from apple orchards, ovipositing queens were significantly 208 heavier than workers (mass ratio $=4.89(\mathrm{SE}=0.499), \mathrm{z}=15.549, p<0.0001)$, males (mass ratio $209=2.45(\mathrm{SE}=0.246), \mathrm{z}=8.952, p<0.0001)$, and young queens $($ mass ratio $=1.44(\mathrm{SE}=0.147), \mathrm{z}$

$210=3.544, p=0.0203)$. Young queens were significantly heavier than workers (mass ratio $=3.40$

$211(\mathrm{SE}=0.297), \mathrm{z}=14.015, p<0.0001)$, and males (mass ratio $=1.71(\mathrm{SE}=0.144), \mathrm{z}=6.336, p<$

212 0.0001). Males were significantly heavier than workers (mass ratio $=1.99(\mathrm{SE}=0.164), \mathrm{z}=$ $2138.384, p<0.0001)$.

214

215 Regarding specimens collected from oilseed rape fields, ovipositing queens were also 216 significantly heavier than workers (mass ratio $=4.34(\mathrm{SE}=0.357), \mathrm{z}=17.829, p<0.0001)$, 217 males $($ mass ratio $=2.75(\mathrm{SE}=0.240), \mathrm{z}=11.592, p<0.0001)$, and young queens $($ mass ratio $=$ $2181.49(\mathrm{SE}=0.134), \mathrm{z}=4.494, p=0.0004)$. Young queens were significantly heavier than workers $219($ mass ratio $=2.90(\mathrm{SE}=0.237), \mathrm{z}=13.053, p<0.0001)$, and males $($ mass ratio $=1.84(\mathrm{SE}=$ $2200.166), \mathrm{z}=6.766, p<0.0001$ ). Males were also significantly heavier than workers (mass ratio $=$ $2211.58(\mathrm{SE}=0.126), \mathrm{z}=5.702, p<0.0001)$.

222

223

\section{Body carbon}

224

225 We observed significant differences in body $\mathrm{C}$ concentration between bumblebee types $\left(\chi^{2}{ }_{(3)}=\right.$ 226 94.15, $p<0.0001$; Fig. 2$)$ and habitats $\left(\chi^{2}(1)=41.75, p<0.0001\right.$; Fig. 2$)$, while interaction of 227 habitat and bumblebee type was not statistically significant $\left(\left(\chi^{2}{ }_{(3)}=7.44, p=0.0651\right)\right.$. 
229 Regarding specimens collected from apple orchards, ovipositing queens had higher body C

230 concentration than males (concentration ratio $=1.04(\mathrm{SE}=0.008), \mathrm{z}=4.702, p=0.0002)$, and

231 workers (concentration ratio $=1.05(\mathrm{SE}=0.010), \mathrm{z}=4.774, p<0.0001)$. Young queens also had

232 higher body $\mathrm{C}$ concentration than workers (concentration ratio $=1.04(\mathrm{SE}=0.009), \mathrm{z}=4.955, p$

$233<0.0005)$, and males (concentration ratio $=1.03(\mathrm{SE}=0.007), \mathrm{z}=4.741, p<0.0001)$.

234 Meanwhile body $\mathrm{C}$ concentration in specimens from apple orchards did not differ significantly

235 between males and workers, and between young and ovipositing queens.

236

237 Regarding specimens collected from oilseed rape fields, ovipositing queens had higher body C

238 concentration than males (concentration ratio $=1.04(\mathrm{SE}=0.008), \mathrm{z}=4.883, p<0.0001)$, and

239 workers (concentration ratio $=1.07(\mathrm{SE}=0.001), \mathrm{z}=7.795, p<0.0001)$. Young queens had

240 higher body $\mathrm{C}$ concentration than workers (concentration ratio $=1.05(\mathrm{SE}=0.009), \mathrm{z}=5.659, p$

$241<0.0001)$. In addition, males had higher body $\mathrm{C}$ concentration that workers (concentration ratio

$242=1.03(\mathrm{SE}=0.008), \mathrm{z}=3.676, p=0.0127)$, but body $\mathrm{C}$ concentration was not significantly

243 different between queen age groups, and between young queens and males.

245 Specimens collected from apple orchards had significantly higher body C concentration, within

246 all bumblebee types compared to specimens collected from oilseed rape fields (all $p \mathrm{~s}<0.0001$ ).

247

248 Body nitrogen

249

250 We observed significant differences in body $\mathrm{N}$ concentration between bumblebee types $\left(\mathrm{F}_{(3 \text {, }}\right.$

251 199.48) $=31.12, p<0.0001$; Fig. 3) and habitats $\left(\mathrm{F}_{(1,6.92)}=36.70, p<0.0006\right.$; Fig. 3). The 
252 interaction between habitat and bumblebee types was also significant $\left(\mathrm{F}_{(3,199.96)}=9.96, p<\right.$

$2530.0001)$.

254

255 Regarding specimens collected from orchards, workers had higher body $\mathrm{N}$ concentration than

256 ovipositing queens (estimated difference $\left.=2.04(\mathrm{SE}=0.35), \mathrm{t}_{(173)}=5.741, p<0.0001\right)$, and

257 males (estimated difference $\left.=2.67(\mathrm{SE}=0.28), \mathrm{t}_{(180)}=9.49, p<0.0001\right)$. Young queens had

258 higher body $\mathrm{N}$ concentration than males (estimated difference $=1.77(\mathrm{SE}=0.06), \mathrm{t}_{(197)}=5.863, p$ $259<0.0001)$

260

261 Regarding specimens collected from oilseed rape fields, young queens had higher body $\mathrm{N}$

262 concentration compared to ovipositing queens (estimated difference $=1.47(\mathrm{SE}=0.32), \mathrm{t}_{(209)}=$

$2634.617, p<0.0005)$. In addition, workers had higher body $\mathrm{N}$ concentration than ovipositing

264 queens (estimated difference $\left.=1.22(\mathrm{SE}=0.29), \mathrm{t}_{(207)}=4.618, p<0.003\right)$.

265

266 Queens and workers from apple orchards had higher body N concentrations compared to those

267 collected from oilseed rape fields (all $p \mathrm{~s}<0.0007$ ), whereas males did not differ significantly in

268 body $\mathrm{N}$ between apple orchards and oilseed rape fields.

\section{$\mathrm{C} / \mathrm{N}$ ratio}

271 We observed significant differences in the $\mathrm{C} / \mathrm{N}$ ratio between bumblebee types $\left(\chi_{(3)}^{2}=136.76, p\right.$

$272<0.0001$; Fig. 4) and habitats $\left(\chi^{2}(1)=14.79, p<0.0002\right.$; Fig. 4). The interaction between habitat 273 and bumblebee types was also significant $\left(\chi_{(3)}^{2}=19.33, p<0.0003\right)$. 
275 Regarding specimens collected from apple orchards, body C/N ratio was significantly higher 276 males compared to workers (value ratio $=1.414(\mathrm{SE}=0.054), \mathrm{z}=9.022, p<0.0001)$ and young

277 queens (value ratio $=1.247(\mathrm{SE}=0.052), \mathrm{z}=5.286, p<0.0001)$. Ovipositing queens also had

278 higher body $\mathrm{C} / \mathrm{N}$ ratio than workers (value ratio $=1.338(\mathrm{SE}=0.069), \mathrm{z}=5.633, p<0.0001)$, 279 and young queens (value ratio $=1.180(\mathrm{SE}=0.063), \mathrm{z}=3.092, p=0.0107)$.

280

281 Regarding specimens collected from oilseed rape fields, ovipositing queens had higher body C/N 282 ratios than workers (value ratio $=1.35(\mathrm{SE}=0.05), \mathrm{z}=7.43, p<0.0001)$, males (value ratio $=$ $2831.19(\mathrm{SE}=0.05), \mathrm{z}=3.96, p<0.005)$, and young queens (value ratio $=1.33(\mathrm{SE}=0.06), \mathrm{z}=$ $2846.49, p<0.0001)$. Additionally, males had significantly higher body $\mathrm{C} / \mathrm{N}$ ratio than worker 285 bumblebees (value ratio $=1.14(\mathrm{SE}=0.05), \mathrm{z}=3.29, p<0.047)$.

286

287 Young queens, ovipositing queens, and workers from apple orchards had significantly lower 288 body $\mathrm{C} / \mathrm{N}$ ratios compared to corresponding caste members collected from oilseed rape fields (all 289 $p \mathrm{~s}<0.0001)$, whereas males did not differ between habitats significantly.

\section{Number of worker- and queen cocoons}

Regarding $B$. terrestris nests collected from oilseed rape fields, the number of worker cocoons eclosed $\left(\chi_{(1)}^{2}=8.56, p=0.003\right.$, Fig. 5A) and total numbers of worker cocoons $\left(\chi^{2}(1)=3.89, p=\right.$ 0.049, Fig. 5B) were significantly higher than in nests collected from apple orchards. There was no significant difference between habitats, regarding number of queen cocoons eclosed $\left(\chi_{(1)}^{2}=\right.$ 
$2971.21, p=0.271$, Fig. 5C), total number of queen cocoons $\left(\chi_{(1)}^{2}=1.15, p=0.284\right.$, Fig. 5D) and

298 the number of worker- $\left(\chi_{(1)}^{2}=2.10, p=0.148\right)$ or queen cocoons intact $\left(\chi^{2}{ }_{(1)}=2.58, p=0.108\right)$.

299

300 Number of pollen- and wax cells

301

302 We observed a significantly higher number of pollen cells $\left(\chi_{(1)}^{2}=11.3, p<0.001\right.$, Fig. 5E $)$ in $B$.

303 terrestris nests collected from oilseed rape fields, compared to nests collected from apple

304 orchards, but there was no significant difference for the number of wax cells $\left(\chi_{(1)}^{2}=3.11, p=\right.$ 305 0.078, Fig. 5F).

306

307

308 Discussion

309

310 Theory predicts that environmental change and associated physiological reactions should alter

311 the macronutrient demands of stressed organisms and affect their development and reproductive

312 strategies (Hawlena \& Schmitz, 2010b; Schmitz, Rosenblatt \& Smylie, 2016; Krams et al.,

313 2020). In this study, we showed that while $B$. terrestris body mass differed between castes, these

314 differences were not present between specimens collected from apple orchards and oilseed rape

315 fields. However, body $\mathrm{C}$ and $\mathrm{N}$ concentrations of bumblebee castes were generally lower in

316 specimens collected from oilseed rape fields compared to apple orchards, while the observed

$317 \mathrm{C} / \mathrm{N}$ ratios were lower in specimens collected from apple orchards compared to oilseed rape

318 fields. Specifically, specimens of young queens, ovipositing queens and workers collected from

319 apple orchards showed lower $\mathrm{C} / \mathrm{N}$ ratios and higher body $\mathrm{N}$ concentrations compared to 
320 corresponding specimens collected from oilseed rape fields. Since a higher $\mathrm{C} / \mathrm{N}$ ratio is often

321 considered to be an indicator of stress, we suggest that all castes of $B$. terrestris except males

322 likely experienced functionally higher stress levels in oilseed rape fields than in apple orchards.

323

324 Apple trees and oilseed rape are both important agricultural plants. Oilseed rape cultivation

325 severely depletes the soil of nutrients, and thus requires large amounts of fertilizers, which is not

326 typical for cultivation of apple trees (Colnenne, 1998; Dubousset, Etienne \& Avice, 2010). This

327 suggests that oilseed rape invests significant resources into intense growth, as well as the

328 flowering that provides pollinators with food resources. Therefore, oilseed rape is considered a

329 nectar- and pollen rich crop (Berrocoso et al., 2015; Bertazzini \& Forlani, 2016). Nectar is

330 important to adult bumblebees as a source of carbohydrates for sustaining flight and foraging.

331 Pollen is crucial to the development of larvae, as it is the principal source of proteins (Kriesell,

332 Hilpert \& Leonhardt, 2017). Both of these food resources are abundant over the course of four to

333 six weeks in oilseed rape agroecosystems (depending on cultivar) (Woodcock et al., 2016). The

334 enormous flower density and abundant nectar and pollen resources provided by oilseed rape

335 benefit such oilseed rape-foraging bumblebee species as B. terrestris (Hoyle, Hayter \&

336 Cresswell, 2007; Kleijn et al., 2015). Mass-flowering of oilseed rape attracts pollinators,

337 potentially resulting in underpollination of other local plant species such as native wildflowers

338 (Holzschuh et al., 2011). In contrast, flowering apple trees are highly attractive to bumblebees

339 for a maximum of ten days during their mass-flowering period in our study region. Accordingly,

340 bumblebee colonies may grow faster when located in- or around oilseed rape fields;

341 subsequently, the colonies will start producing the reproductive generation (males and young

342 queens) earlier than would occur in apple orchards (Woodcock et al., 2016). Since life history 
343 traits reflect the differential allocation of different resources to competing life functions

344 (Speakman \& Garratt, 2014), trade-offs between higher resource abundance and more intense

345 reproductive investments may result in higher stress levels caused by the tremendous

346 reproductive effort of bumblebees in oilseed rape fields.

348 Our data show that higher $\mathrm{C} / \mathrm{N}$ ratios in bumblebees collected from oilseed rape fields coincides 349 with much higher reproductive output in this habitat compared to apple orchards. The higher 350 total number of worker cocoons, and larger amounts of food resources (pollen cells), were

351 observed in hives collected from oilseed rape fields, compared to those collected from apple

352 orchards. More food evidently allowed bumblebees in oilseed rape fields to invest in

353 reproduction, resulting in a significantly higher number of workers and young queens produced.

354 Reproduction comes at the cost of affecting lifespan, immunity, and other life history traits

355 (Lawniczak et al., 2007; Harshman \& Zera, 2007), while extra physical activities may be 356 detrimental for longevity (Tanaka et al., 2019; Hayashi \& Kezuka, 2020). The production of sex

357 hormones can also mediate the cost of reproduction by trading off higher investment in

358 reproduction against decreased investment into somatic functions (Harshman \& Zera, 2007).

360 Food quality and energetic value are of particular importance in life history decisions, and can 361 greatly enhance an organism's investment in reproduction and fitness when available ad libitum

362 (Krams et al., 2015, 2017). Thus, food availability often improves reproductive success, which

363 we may have observed here with regard to bumblebees inhabiting oilseed rape fields. However,

364 as investments in reproduction often compete with the immune system for the same resources,

365 high reproductive investment and fitness-gain can come at the expense of stress reflected in 
366 higher $\mathrm{C} / \mathrm{N}$ ratios found in workers, ovipositing queens, and young queens inhabiting oilseed

367 rape agroecosystems. The absence of a significant difference between the $\mathrm{C} / \mathrm{N}$ ratios of males in

368 apple orchards and oilseed rape fields supports the idea that a higher $\mathrm{C} / \mathrm{N}$ ratio may be due to an

369 investment in reproduction, as well as the associated high-intensity foraging behavior observed

370 in ovipositing queens, young queens and workers in oilseed rape fields. It is important to note

371 that the availability of nectar and pollen in oilseed rape fields sharply ends before the end of

372 bumblebee reproductive season (Carvell et al., 2011; Williams, Regetz \& Kremen, 2012;

373 Woodcock et al., 2016), which is not the case in apple orchards where bumblebees rely on many

374 other plants besides apple trees. It has been found that while abundance of foraging resources is

375 of high importance for worker production in bumblebees (Westphal, Steffan-Dewenter \&

376 Tscharntke, 2009; Woodcock et al., 2016), queen production and population sustainability

377 depends on resource availability during the whole breeding season (Williams, Regetz \& Kremen,

378 2012; Woodcock et al., 2016). Our results fully support these findings showing higher

379 investment in worker production in B. terrestris breeding in oilseed rape fields and similar effort

380 in queen production in apple orchards and oilseed rape fields. Future research should measure

381 lifespan and investigate the immune system of bumblebees reproducing in different habitats,

382 including the most optimal habitats for pollen and nectar availability to better understand the role

383 of ecological factors such as floral phenology in trade-offs between life history traits.

385 Our data suggest that apple orchards may be an optimal habitat for certain bumblebees. This may 386 be due to the higher proportion of trees having a positive impact on biodiversity and abundance

387 of bumblebees (Sõber et al., 2020). However, the flowering season for apple trees is relatively

388 short, subsequently increasing $B$. terrestris's body $\mathrm{N}$ demand, as this element is found in muscles 
389 required for longer foraging flights. In contrast, bumblebees can find food within the vicinity of

390 their hives in- and around oilseed rape fields, decreasing their body $\mathrm{N}$ demand (Krams et al.,

391 2021b). This shows that flora phenology must be taken into account to better understand the role

392 of habitat quality on survival and reproductive strategies of pollinators.

393

394 It is important to note that bumblebees and their hives may be relatively more exposed to direct 395 sunlight in oilseed rape agroecosystems than in apple orchards. This could lower the need for 396 excess carbohydrate-rich food, and decrease their body C concentration. Under lower ambient

397 temperatures, or no access to direct sunlight, bumblebees must warm up to fly and forage (Bujok

398 et al., 2002; Seeley et al., 2003). Bumblebee flight muscles must reach at least $30^{\circ} \mathrm{C}$ in order for

399 the bumblebee to become airborne (Goller \& Esch, 1990). Generation of heat can be achieved

400 via flight muscle shivering, as well as in the absence of shivering, by means of receiving action

401 potentials (Esch, Goller \& Heinrich, 1991). If bumblebee hives are more exposed to the direct

402 sunlight, these muscle-associated heat generating activities may be less needed, explaining lower

403 body $\mathrm{N}$ concentration in bumblebees collected from oilseed rape fields. More favorable ambient

404 temperatures could also explain the lower body $\mathrm{C}$ concentrations we observed in bumblebees

405 collected from oilseed rape fields, as less carbohydrate-based fuel is required for thermogenesis

406 in warmer habitats.

407

408 Finally, lower body $\mathrm{N}$ concentrations and higher $\mathrm{C} / \mathrm{N}$ ratios in specimens collected from oilseed

409 rape fields, compared to apple orchards, may be explained by greater investments in

410 reproduction in terms of offspring number, and less so in their somatic growth, because

411 bumblebees could potentially reach larger sizes when living in oilseed rape agroecosystems. It 
412 was observed that grasshoppers consume and process more proteins under higher ambient

413 temperatures (Schmitz, Rosenblatt \& Smylie, 2016), and we suggest that in bumblebees a similar

414 relationship may result in more rapid development of workers and higher reproductive output, as

415 we observed in hives collected from oilseed rape fields. Therefore, relationships between

416 investment in offspring production, temperature effects, and body $\mathrm{C}$ - and $\mathrm{N}$ concentrations

417 should be investigated in future research.

418

419 Conclusions

420

421 We found significant differences in reproductive success, body C- and N concentrations, and

$422 \mathrm{C} / \mathrm{N}$ ratio of $B$. terrestris types (workers, young queens, ovipositing queens, males) in two

423 agricultural habitats. Surprisingly, our results show that reproductive output was significantly

424 higher in oilseed rape fields than in apple orchards, the latter being considered a more natural

425 habitat due to the presence of several layers of vegetation. On the other hand, physiological

426 stress, indicated by the higher $\mathrm{C} / \mathrm{N}$ ratios of queens and workers, was lower in apple orchards.

427 This suggests that bumblebees can achieve higher fitness when reproducing in oilseed rape

428 fields. Our study highlights a positive impact of high-intensity oilseed rape cultivation,

429 particularly the achievement of meeting the nutritional requirements of animals (Knutie, Chaves

$430 \&$ Gotanda, 2019), in this case the bumblebee $B$. terrestris. We suggest that approaches based on

431 ecological stoichiometry may be instrumental in building on the knowledge of how habitat

432 quality can affect pollinators. In this study, we did not carry out any experimental tests to provide

433 additional resources to manipulate the duration of food availability in the apple orchards.

434 Although these tests could help validate our results, extra sucrose solution cannot replace the 
435 whole quality of the habitat, consisting of different floral resources, microclimate and

436 microorganisms, and pollen. While we plan to perform such experimental trials in the future,

437 they require extra caution.

438

439

\section{Author Contributions}

440

R.K., T.K., J.C.G., and I.A.K. designed research; R.K., S.P., M.M., T.K. and I.A.K performed

441 research; R.K., M.M., T.K., S.P., L.D. analyzed samples; R.K., M.M., J.C.G., L.D., and I.A.K.

442 analyzed data; and T.K., R.K., J.W., P.R., M.M., I.A.K. wrote the paper. All authors contributed

443 to the article and approved the submitted version.

444

445 Funding

446 This work was supported by the Latvian Council of Science (grants lzp-2018/1-0393, lzp-

447 2018/2- 00057, lzp-2020/2-0271, lzp-2021/1-0277), and the European Union, European Regional

448 Development Fund (Estonian University of Life Sciences ASTRA project "Value-chain based

449 bioeconomy").

450

451 Acknowledgments

452 The authors thank Professor Māris Kḷaviņš for supporting this project at the stage of lab

453 analyses.

454

455 Conflict of Interests Statement

456 The authors declare that they have no known competing financial interests or personal

457 relationships that could have appeared to influence the work reported in this paper. 
459 Data availability

460 The dataset has been deposited to Zenodo repository (doi.org/10.5281/zenodo.5128075).

461

462

\section{REFERENCES}

464

d’Andrimont R, Taymans M, Lemoine G, Ceglar A, Yordanov M, van der Velde M. 2020. Detecting flowering phenology in oil seed rape parcels with Sentinel-1 and -2 time series. Remote Sensing of Environment 239:111660. DOI: 10.1016/j.rse.2020.111660.

Bartual AM, Sutter L, Bocci G, Moonen A-C, Cresswell J, Entling M, Giffard B, Jacot K, Jeanneret P, Holland J, Pfister S, Pintér O, Veromann E, Winkler K, Albrecht M. 2019. The potential of different semi-natural habitats to sustain pollinators and natural enemies in European agricultural landscapes. Agriculture, Ecosystems \& Environment 279:43-52. DOI: 10.1016/j.agee.2019.04.009.

Bates D, Maechler M, Bolker B, Walker S. 2015. Mixed-effects models using Ime4. Journal of Statistical Software 67:1-48.

Berrocoso JD, Rojas OJ, Liu Y, Shoulders J, González-Vega JC, Stein HH. 2015. Energy concentration and amino acid digestibility in high-protein canola meal, conventional canola meal, and soybean meal fed to growing pigs. Journal of Animal Science 93:22082217. DOI: 10.2527/jas.2014-8528. 
479 Bertazzini M, Forlani G. 2016. Intraspecific Variability of Floral Nectar Volume and Composition in Rapeseed (Brassica napus L. var. oleifera). Frontiers in Plant Science 7. DOI: 10.3389/fpls.2016.00288.

482 483 89:299-301. DOI: 10.1007/s00114-002-0338-7.

484 Carvell C, Osborne JL, Bourke AFG, Freeman SN, Pywell RF, Heard MS. 2011. Bumble bee 485 species' responses to a targeted conservation measure depend on landscape context 486 and habitat quality. Ecological Applications 21:1760-1771. DOI: 10.1890/10-0677.1.

487 Colnenne C. 1998. Determination of a Critical Nitrogen Dilution Curve for Winter Oilseed Rape. 488 Annals of Botany 81:311-317. DOI: 10.1006/anbo.1997.0557.

Crall JD, Switzer CM, Oppenheimer RL, Ford Versypt AN, Dey B, Brown A, Eyster M, Guérin C, Pierce NE, Combes SA, de Bivort BL. 2018. Neonicotinoid exposure disrupts bumblebee nest behavior, social networks, and thermoregulation. Science 362:683-686. DOI:

492 10.1126/science.aat1598.

493

De Senerpont Domis LN, Van de Waal DB, Helmsing NR, Van Donk E, Mooij WolfM. 2014. Community stoichiometry in a changing world: combined effects of warming and 495 eutrophication on phytoplankton dynamics. Ecology 95:1485-1495. DOI: 10.1890/13-

496 1251.1.

497

Dubousset L, Etienne P, Avice JC. 2010. Is the remobilization of $\mathrm{S}$ and $\mathrm{N}$ reserves for seed filling 498 of winter oilseed rape modulated by sulphate restrictions occurring at different growth 499 stages? Journal of Experimental Botany 61:4313-4324. DOI: 10.1093/jxb/erq233. 
500 Esch H, Goller F, Heinrich B. 1991. How do bees shiver? The Science of Nature 78:325-328. DOI:

501

502

503

504

505

506

507

508

509

510

511

512

513

514

515

516

517

518

519

520

521

10.1007/BF01221422.

Filipiak M. 2018. A Better Understanding of Bee Nutritional Ecology Is Needed to Optimize Conservation Strategies for Wild Bees-The Application of Ecological Stoichiometry. Insects 9:85. DOI: 10.3390/insects9030085.

Filipiak M, Kuszewska K, Asselman M, Denisow B, Stawiarz E, Woyciechowski M, Weiner J. 2017. Ecological stoichiometry of the honeybee: Pollen diversity and adequate species composition are needed to mitigate limitations imposed on the growth and development of bees by pollen quality. PLOS ONE 12:e0183236. DOI: 10.1371/journal.pone.0183236.

Filipiak M, Weiner J. 2017. Plant-insect interactions: the role of ecological stoichiometry. Acta Agrobotanica 70:1-16.

Filipiak M, Woyciechowski M, Czarnoleski M. 2021. Stoichiometric niche, nutrient partitioning and resource allocation in a solitary bee are sex-specific and phosphorous is allocated mainly to the cocoon. Scientific Reports 11:652. DOI: 10.1038/s41598-020-79647-7.

Garibaldi LA, Steffan-Dewenter I, Winfree R, Aizen MA, Bommarco R, Cunningham SA, Kremen C, Carvalheiro LG, Harder LD, Afik O, Bartomeus I, Benjamin F, Boreux V, Cariveau D, Chacoff NP, Dudenhoffer JH, Freitas BM, Ghazoul J, Greenleaf S, Hipolito J, Holzschuh A, Howlett B, Isaacs R, Javorek SK, Kennedy CM, Krewenka KM, Krishnan S, Mandelik Y, Mayfield MM, Motzke I, Munyuli T, Nault BA, Otieno M, Petersen J, Pisanty G, Potts SG, Rader R, Ricketts TH, Rundlof M, Seymour CL, Schuepp C, Szentgyorgyi H, Taki H, Tscharntke T, Vergara CH, Viana BF, Wanger TC, Westphal C, Williams N, Klein AM. 2013. 
Wild Pollinators Enhance Fruit Set of Crops Regardless of Honey Bee Abundance. Science 339:1608-1611. DOI: 10.1126/science.1230200.

524 Goller F, Esch H. 1990. Comparative study of chill-coma temperatures and muscle potentials in insect flight muscles. Journal of Experimental Biology 150:221-231.

526 Goulson D. 2012. Bumblebees: Behaviour, Ecology, and Conservation. Oxford: Oxford University Press.

528 Goulson D, Nicholls E, Botias C, Rotheray EL. 2015. Bee declines driven by combined stress from parasites, pesticides, and lack of flowers. Science 347:1255957-1255957. DOI: 10.1126/science.1255957.

531 Harshman LG, Zera AJ. 2007. The cost of reproduction: the devil in the details. Trends in Ecology \& Evolution 22:80-86. DOI: 10.1016/j.tree.2006.10.008.

Hawlena D, Schmitz OJ. 2010a. Herbivore physiological response to predation risk and implications for ecosystem nutrient dynamics. Proceedings of the National Academy of Sciences 107:15503-15507. DOI: 10.1073/pnas.1009300107.

Hawlena D, Schmitz OJ. 2010b. Physiological Stress as a Fundamental Mechanism Linking Predation to Ecosystem Functioning. The American Naturalist 176:537-556. DOI: $10.1086 / 656495$. crops leads to transient pollinator dilution and reduced wild plant pollination. Proceedings of the Royal Society B: Biological Sciences 278:3444-3451. DOI: 10.1098/rspb.2011.0268. 
544 Hoyle M, Hayter K, Cresswell JE. 2007. EFFECT OF POLLINATOR ABUNDANCE ON SELFFERTILIZATION AND GENE FLOW: APPLICATION TO GM CANOLA. Ecological Applications 17:2123-2135. DOI: 10.1890/06-1972.1.

547 Huang D, Wang D, Ren Y. 2019. Using leaf nutrient stoichiometry as an indicator of flood tolerance and eutrophication in the riparian zone of the Lijang River. Ecological Indicators 98:821-829. DOI: 10.1016/j.ecolind.2018.11.064.

550

551

552

553

554

555

556

557

558

559

560

561

562

563

564
Jachuła J, Denisow B, Wrzesień M. 2021. Habitat heterogeneity helps to mitigate pollinator nectar sugar deficit and discontinuity in an agricultural landscape. Science of The Total Environment 782:146909. DOI: 10.1016/j.scitotenv.2021.146909.

Janssens L, Op de Beeck L, Stoks R. 2017. Stoichiometric Responses to an Agricultural Pesticide Are Modified by Predator Cues. Environmental Science \& Technology 51:581-588. DOI: 10.1021/acs.est.6b03381.

Janssens L, Van Dievel M, Stoks R. 2015a. Warming reinforces nonconsumptive predator effects on prey growth, physiology, and body stoichiometry. Ecology 96:3270-3280. DOI: 10.1890/15-0030.1.

Janssens L, Van Dievel M, Stoks R. 2015b. Warming reinforces nonconsumptive predator effects on prey growth, physiology, and body stoichiometry. Ecology 96:3270-3280. DOI: 10.1890/15-0030.1.

Kämper W, Weiner C, Kühsel S, Storm C, Eltz T, Blüthgen N. 2017. Evaluating the effects of floral resource specialisation and of nitrogen regulation on the vulnerability of social bees in agricultural landscapes. Apidologie 48:371-383. DOI: 10.1007/s13592-016-0480-4. 
565 Kleijn D, Winfree R, Bartomeus I, Carvalheiro LG, Henry M, Isaacs R, Klein A-M, Kremen C,

566

567

568

569

570

571

572

573

574

575

576

577

578

579

580

581

582

583

584

585
M’Gonigle LK, Rader R, Ricketts TH, Williams NM, Lee Adamson N, Ascher JS, Báldi A, Batáry P, Benjamin F, Biesmeijer JC, Blitzer EJ, Bommarco R, Brand MR, Bretagnolle V, Button L, Cariveau DP, Chifflet R, Colville JF, Danforth BN, Elle E, Garratt MPD, Herzog F, Holzschuh A, Howlett BG, Jauker F, Jha S, Knop E, Krewenka KM, Le Féon V, Mandelik Y, May EA, Park MG, Pisanty G, Reemer M, Riedinger V, Rollin O, Rundlöf M, Sardiñas HS, Scheper J, Sciligo AR, Smith HG, Steffan-Dewenter I, Thorp R, Tscharntke T, Verhulst J, Viana BF, Vaissière BE, Veldtman R, Ward KL, Westphal C, Potts SG. 2015. Delivery of crop pollination services is an insufficient argument for wild pollinator conservation. Nature Communications 6:7414. DOI: 10.1038/ncomms8414.

Knutie SA, Chaves JA, Gotanda KM. 2019. Human activity can influence the gut microbiota of Darwin's finches in the Galapagos Islands. Molecular Ecology 28:2441-2450. DOI: 10.1111/mec.15088.

Krams I, Eichler Inwood S, Trakimas G, Krams R, Burghardt GM, Butler DM, Luoto S, Krama T. 2016. Short-term exposure to predation affects body elemental composition, climbing speed and survival ability in Drosophila melanogaster. PeerJ 4:e2314. DOI: 10.7717/peerj.2314.

Krams IA, Kecko S, Jõers P, Trakimas G, Elferts D, Krams R, Luoto S, Rantala MJ, Inashkina I, Gudrā D, Fridmanis D, Contreras-Garduño J, Grantiṇa-leviṇa L, Krama T. 2017. Microbiome symbionts and diet diversity incur costs on the immune system of insect larvae. The Journal of Experimental Biology 220:4204-4212. DOI: 10.1242/jeb.169227. 
586 Krams I, Kecko S, Kangassalo K, Moore FR, Jankevics E, Inashkina I, Krama T, Lietuvietis V, Meija

L, Rantala MJ. 2015. Effects of food quality on trade-offs among growth, immunity and survival in the greater wax moth Galleria mellonella: Food quality and life history tradeoffs. Insect Science 22:431-439. DOI: 10.1111/1744-7917.12132.

Krams I, Kivleniece I, Kuusik A, Krama T, Freeberg TM, Mänd R, Vrublevska J, Rantala MJ, Mänd M. 2013a. Predation selects for low resting metabolic rate and consistent individual differences in anti-predator behavior in a beetle. acta ethologica 16:163-172. DOI: 10.1007/s10211-013-0147-3.

Krams I, Kivleniece I, Kuusik A, Krama T, Mänd R, Rantala MJ, Znotiṇa S, Freeberg TM, Mänd M. 2013b. Predation promotes survival of beetles with lower resting metabolic rates. Entomologia Experimentalis et Applicata 148:94-103. DOI: 10.1111/eea.12079.

Krams R, Krama T, Munkevics M, Eichler S, Butler DM, Dobkeviča L, Jõers P, Contreras-GarduÑo J, Daukšte J, Krams IA. 2021a. Spider odors induce stoichiometric changes in fruit fly Drosophila melanogaster. Current Zoology 67:127-129. DOI: 10.1093/cz/zoaa070.

Krams IA, Krams R, Jõers P, Munkevics M, Trakimas G, Luoto S, Eichler S, Butler DM, Merivee E, Must A, Rantala MJ, Contreras-Garduño J, Krama T. 2020. Developmental speed affects ecological stoichiometry and adult fat reserves in Drosophila melanogaster. Animal Biology 71:1-20. DOI: 10.1163/15707563-bja10043.

Krams R, Munkevics M, Popovs S, Dobkeviča L, Willow J, Contreras Garduño J, Krama T, Krams IA. 2021b. Ecological Stoichiometry of Bumblebee Castes, Sexes, and Age Groups. Frontiers in Physiology 12:696689. DOI: 10.3389/fphys.2021.696689. 
607 Kremen C, Williams NM, Thorp RW. 2002. Crop pollination from native bees at risk from

608 agricultural intensification. Proceedings of the National Academy of Sciences 99:16812-

609 16816. DOI: 10.1073/pnas.262413599.

610 Kriesell L, Hilpert A, Leonhardt SD. 2017. Different but the same: bumblebee species collect

611 pollen of different plant sources but similar amino acid profiles. Apidologie 48:102-116.

612 DOI: 10.1007/s13592-016-0454-6.

613 Kuznetsova A, Brockhoff PB, Christensen RHB. 2017. ImerTest package: Tests in linear mixed

614 effects models. Journal of Statistical Software 82:1-26.

615 Lawniczak M, Barnes A, Linklater J, Boone J, Wigby S, Chapman T. 2007. Mating and immunity in 616 invertebrates. Trends in Ecology \& Evolution 22:48-55. DOI: 10.1016/j.tree.2006.09.012.

617 Lenth R, Buerkner P, Herve M. 2021. emmeans: Estimated Marginal Means, aka Least-Squares

$618 \quad$ Means. R package version 1.5.4.

619 Lever JJ, van Nes EH, Scheffer M, Bascompte J. 2014. The sudden collapse of pollinator 620 communities. Ecology Letters 17:350-359. DOI: 10.1111/ele.12236.

621 Martínez-Sastre R, Miñarro M, García D. 2020. Animal biodiversity in cider apple orchards:

622 Simultaneous environmental drivers and effects on insectivory and pollination.

623 Agriculture, Ecosystems \& Environment 295:106918. DOI: 10.1016/j.agee.2020.106918.

624 R Core Team. 2021. A language and environment for statisctical computing. Vienna, Austria.: R

$625 \quad$ Foundation for Statistical Computing.

626 Riddell CE, Mallon EB. 2006. Insect psychoneuroimmunology: Immune response reduces

627 learning in protein starved bumblebees (Bombus terrestris). Brain, Behavior, and

628 Immunity 20:135-138. DOI: 10.1016/j.bbi.2005.06.008. 
629 Rinehart S, Hawlena D. 2020. The effects of predation risk on prey stoichiometry: a

630 meta-analysis. Ecology 101. DOI: 10.1002/ecy.3037.

631 Schmitz OJ, Rosenblatt AE, Smylie M. 2016. Temperature dependence of predation stress and 632

633 the nutritional ecology of a generalist herbivore. Ecology 97:3119-3130. DOI:

634

Seeley TD, Kleinhenz M, Bujok B, Tautz J. 2003. Thorough warm-up before take-off in honey bee

swarms. Naturwissenschaften 90:256-260. DOI: 10.1007/s00114-003-0425-4.

Simanonok MP, Burkle LA. 2020. High-severity wildfire limits available floral pollen quality and bumble bee nutrition compared to mixed-severity burns. Oecologia 192:489-499. DOI: 10.1007/s00442-019-04577-9.

Slos S, Stoks R. 2008. Predation risk induces stress proteins and reduces antioxidant defense. Functional Ecology 22:637-642. DOI: 10.1111/j.1365-2435.2008.01424.x.

641

642 643

$$
\text { 10.1002/ecy.1524. }
$$
10.1002/ecy.1524. 
651

652

653

654

655

656

657

658

659

660

661

662

663

664

665

666

667

668

669

670

671

672 occupational class among men in Japan, South Korea and eight European countries: a national register-based study, 1990-2015. Journal of Epidemiology and Community Health 73:750-758. DOI: 10.1136/jech-2018-211715.

Trakimas G, Krams R, Krama T, Kortet R, Haque S, Luoto S, Eichler Inwood S, Butler DM, Jõers P, Hawlena D, Rantala MJ, Elferts D, Contreras-Garduño J, Krams I. 2019. Ecological Stoichiometry: A Link Between Developmental Speed and Physiological Stress in an Omnivorous Insect. Frontiers in Behavioral Neuroscience 13:42. DOI: 10.3389/fnbeh.2019.00042.

Tromp J. 1976. Flower-bud formation and shoot growth in apple as affected by temperature. Scientia Horticulturae 5:331-338. DOI: 10.1016/0304-4238(76)90128-X.

Van Dievel M, Janssens L, Stoks R. 2016. Short- and long-term behavioural, physiological and stoichiometric responses to predation risk indicate chronic stress and compensatory mechanisms. Oecologia 181:347-357. DOI: 10.1007/s00442-015-3440-1.

Van Dievel M, Janssens L, Stoks R. 2020. Effects of pesticide exposure and predation risk on nutrient cycling and primary production. Science of The Total Environment 705:135880. DOI: 10.1016/j.scitotenv.2019.135880.

Westphal C, Steffan-Dewenter I, Tscharntke T. 2009. Mass flowering oilseed rape improves early colony growth but not sexual reproduction of bumblebees. Journal of Applied Ecology 46:187-193. DOI: 10.1111/j.1365-2664.2008.01580.x.

Williams NM, Regetz J, Kremen C. 2012. Landscape-scale resources promote colony growth but not reproductive performance of bumble bees. Ecology 93:1049-1058. DOI: 10.1890/11-1006.1. 
673 Woodcock BA, Isaac NJB, Bullock JM, Roy DB, Garthwaite DG, Crowe A, Pywell RF. 2016.

674 Impacts of neonicotinoid use on long-term population changes in wild bees in England.

$675 \quad$ Nature Communications 7:12459. DOI: 10.1038/ncomms12459.

676 Zhang C, Jansen M, De Meester L, Stoks R. 2016. Energy storage and fecundity explain

677 deviations from ecological stoichiometry predictions under global warming and size-

678 selective predation. Journal of Animal Ecology 85:1431-1441. DOI: 10.1111/1365-

$679 \quad 2656.12531$.

680

681 
Figure 1

Dry body mass of bumblebee males, young queens, ovipositing queens and workers.

Box plots showing dry body mass of males, young queens, ovipositing queens and workers of Bombus terrestris collected from apple orchards and oilseed rape fields.

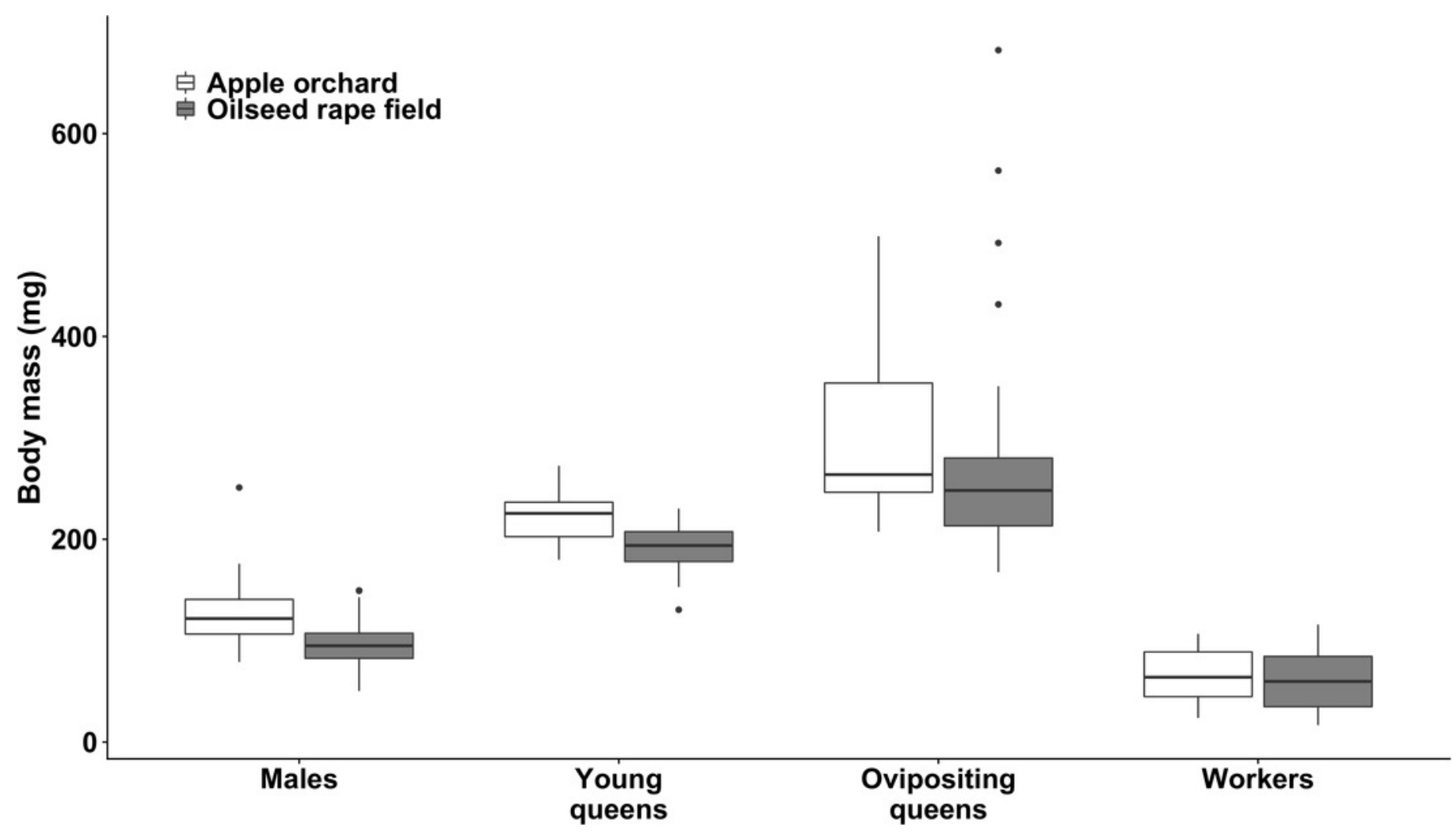


Figure 2

Body carbon concentration of bumblebee males, young queens, ovipositing queens and workers.

Box plots showing body carbon concentrations of males, young queens, ovipositing queens and workers of Bombus terrestris collected from apple orchards and oilseed rape fields. $\mathrm{C}=$ carbon.

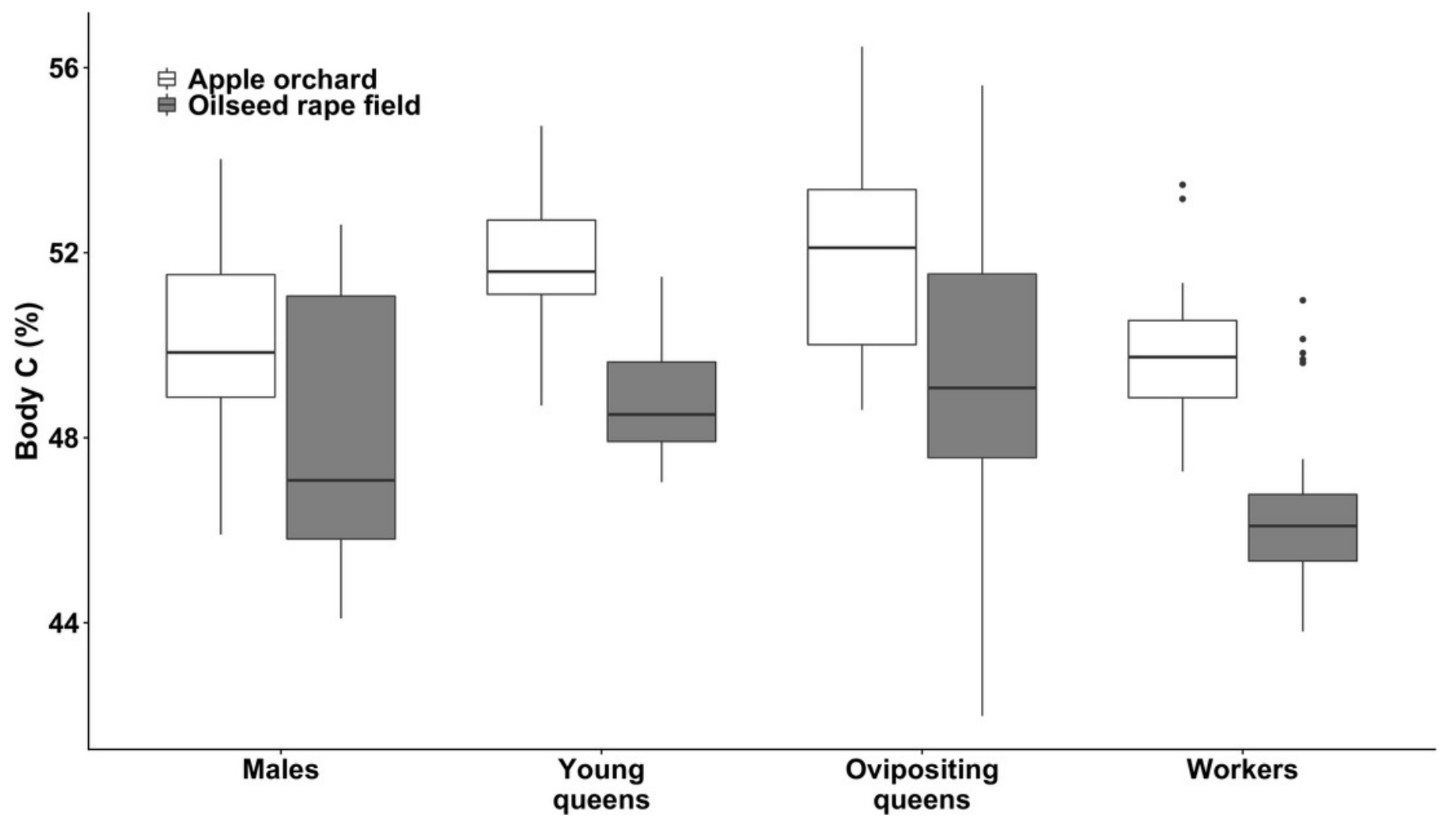


Figure 3

Body nitrogen concentration of bumblebee males, young queens, ovipositing queens and workers.

Box plots showing body nitrogen concentrations of males, young queens, ovipositing queens and workers of Bombus terrestris collected from apple orchards and oilseed rape fields. $\mathrm{N}=$ nitrogen.

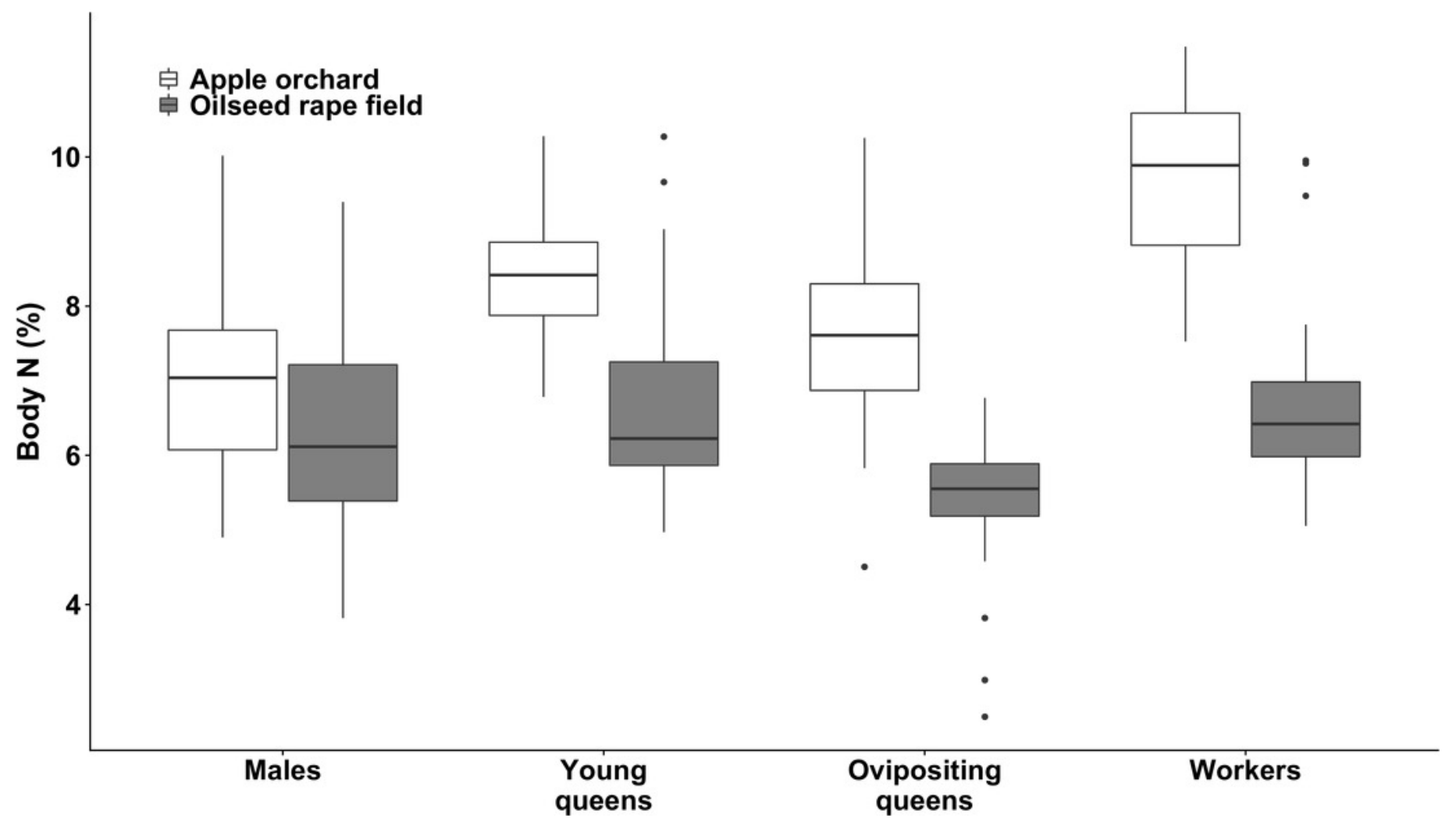


Figure 4

Body carbon to nitrogen ratio of bumblebee males, young queens, ovipositing queens and workers.

Box plots showing body carbon:nitrogen ratio of males, young queens, ovipositing queens and workers of Bombus terrestris collected from apple orchards and oilseed rape fields. $\mathrm{C}=$ carbon, $\mathrm{N}=$ nitrogen.

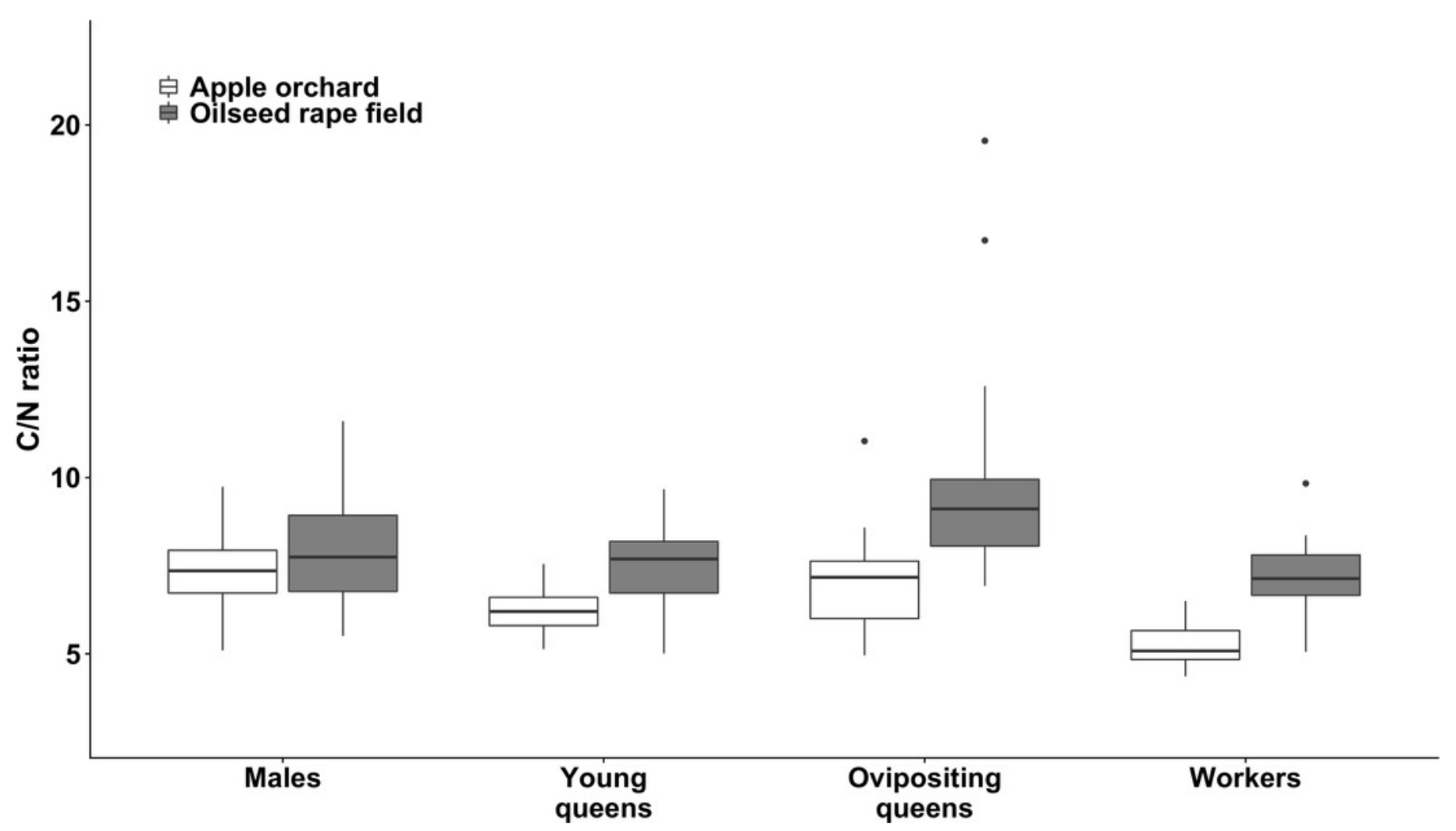




\section{Figure 5}

Reproductive parameters of bumblebees in old apple orchards and oilseed rape fields.

For Bombus terrestris nests collected from apple orchards and oilseed rape fields, box plots showing the number of worker cocoons eclosed (A), total number of worker cocoons (intact and eclosed; B), number of queen cocoons eclosed (C), total number of queen cocoons (intact and eclosed; D), number of pollen cells $(E)$, and number of wax cells $(F)$. 

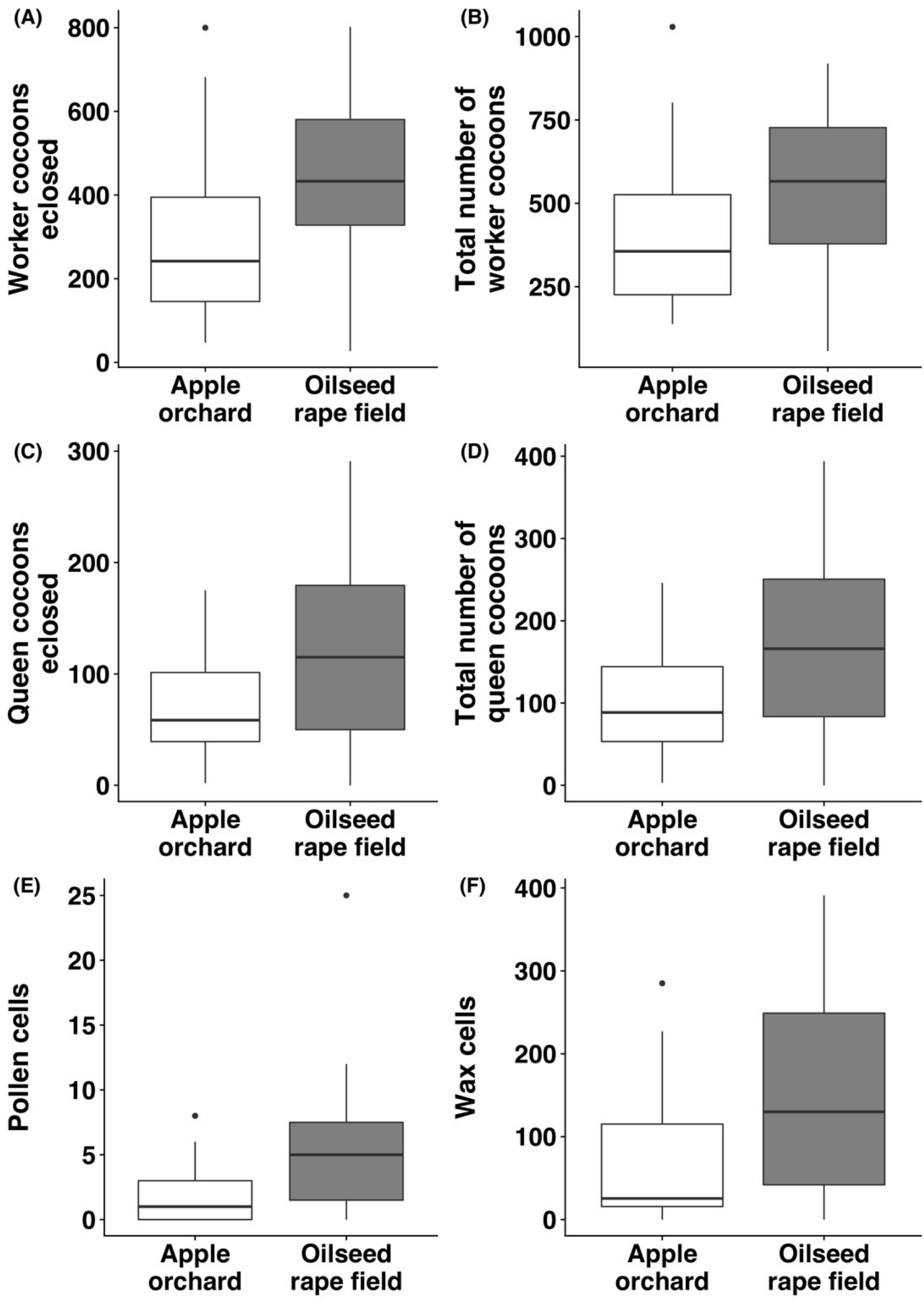